\title{
Dual output DC-DC quasi impedance source converter
}

\author{
Muhammad Ado $^{1}$, Awang Jusoh ${ }^{2}$, Tole Sutikno ${ }^{3}$, Mohd Hanipah Muda ${ }^{4}$, Zeeshan Ahmad Arfeen \\ ${ }^{1,2,5}$ School of Electrical Engineering, Universiti Teknologi Malaysia, Malaysia \\ ${ }^{1}$ Department of Physics, Bayero Univerity, Nigeria \\ ${ }^{3}$ Department of Electrical Engineering, Universitas Ahmad Dahlan, Indonesia \\ ${ }^{4}$ Faculty of Electrical and Automation Engineering Technology, Tati Universiti College, Malaysia \\ ${ }^{5}$ University College of Engineering \& Technology, The Islamia University of Bahawalpur, Pakistan
}

\section{Article Info}

Article history:

Received Jan 30, 2020

Revised Mar 5, 2020

Accepted Mar 15, 2020

\section{Keywords:}

Bidirectional

Buck-boost converters

ABSTRACT

A double output port DC-DC quasi impedance source converter (q-ZSC) is proposed. Each of the outputs has a different voltage gain. One of the outputs is capable of bidirectional (four-quadrant) operation by only varying the duty ratio. The second output has the gain of traditional two-switch buck-boost converter. Operation of the converter was verified by simulating its responses for different input voltages and duty ratios using MATLAB SIMULINK software. Its average steady-state output current and voltage values were determined and used to determine the ripples that existed. These ripples are less than $5 \%$ of the average steady-state values for all the input voltage and duty ratio ranges considered.
\end{abstract}

Converters

Double output

Quasi-Z-source

Z-source

\section{Corresponding Author:}

Awang Jusoh,

School of Electrical Engineering,

Universiti Teknologi Malaysia,

81310 Skudai, Johor, Malaysia.

Email: awang@utm.my
Copyright $(0) 2020$ Insitute of Advanced Engineeering and Science. All rights reserved.

\section{INTRODUCTION}

Use of renewable-energy (RE) generation systems has been dramatically increasing due to environmental effects and the exhaustion of fossil fuels [1]. The major RE sources are photovoltaic (PV) energy, wind power, and fuel cells (FC). The outputs of these RE sources are unregulated, thus require power converters such as DC-DC converters for regulation [2-8]. Functions of these DC-DC converters include regulating the variable output voltages to a given set point to charge the energy storage systems (ESSs) [4], charging and discharging of batteries or other energy storage systems (ESSs) [9], stepping up/down of voltages in fuel cell electric vehicles (FCEVs) [5] and powering DC loads or inverters.

Impedance source converters (ISCs or ZSCs) [10] are types of power converters capable of AC-AC, AC-DC, DC-AC and DC-DC conversion. They couple converter's main circuit by using an impedance network to its input power source and provide other exclusive features [11, 12]. ISCs permit shoot-through (ST) in voltage-fed ISCs without causing over-current for voltage boosting by allowing short-circuiting of their output terminal [13]. They permit open-circuit (OC) in current-fed ISCs by allowing interruption of current for current boosting without causing over-voltage [14]. Turning ON switches of a H-bridge's common leg simultaneously results in ST while turning them ON triggers OC [6].

Inductors are used during ST to store energy that is released later during other modes [15]. ISCs are robust because they could be controlled by PWM signals with or without OC and/or ST modes. Q-ZSCs [16] are class of ISCs obtained by swapping switches and inductors to remedy some limitations of ZSCs. However, 
limitations like discontinuous input current and high voltage stress on switches are still common in some q-ZSC topologies. Incorporating OC modes into the switching signals could reduce switching stress [3].

Q-ZSC application was extended to DC-DC application by taking the output across one of the capacitors [17]. However, [18-20] took their outputs across a switch in what is called pulse-width modulated DC-DC ISCs. M. Ado et al [11] and [21] later proposed additional topology each to form an additional class [22]. M. Ado et al [23] extended the family of DC-DC q-ZSCs from two classes to three and from four members to six. Each of the classes has two members and a unique voltage gain. Although some of the proposed topologies are capable of four-quadrant (bidirectional) energy transfer, they all have single input and single output (SISO) voltages.

This paper presents a DC-DC q-ZSC topology with a single input voltage source and dual output voltage ports as shown in Figure 1. The two outputs have different voltage gains. The significance of having different voltage gains is that two different output voltages could be obtained simultaneously. The operation of the proposed converter was verified by simulating its response in MATLAB SIMULINK. The verification involved simulating its response at different input voltages $\left(\mathrm{V}_{\mathrm{g}}\right)$ and duty ratios $(\mathrm{D})$. The average steady-state output current $\left(\mathrm{I}_{\mathrm{O}}\right)$ and voltages $\left(\mathrm{V}_{\mathrm{O}}\right)$ of each simulation was determined and analyzed. Ripple ratios for these average voltages and currents were determined and compared with theoretical values. The comparison showed that the average voltages were above $89 \%$ of the theoretical values.

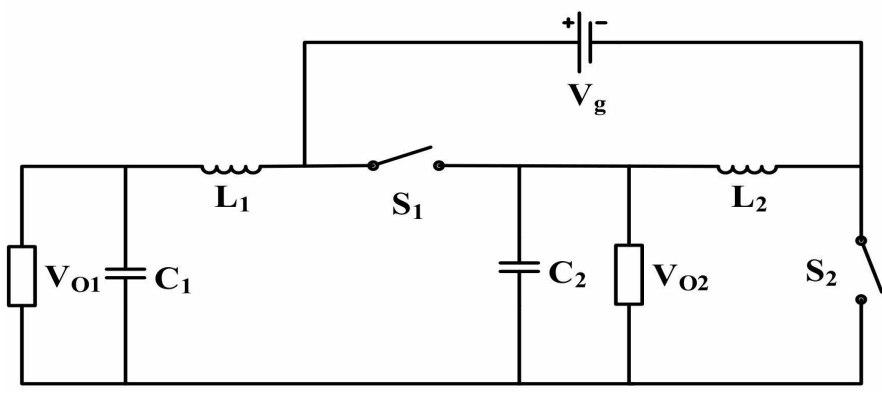

Figure 1. Topology of proposed converter

\section{CIRCUIT ANALYSIS}

For easy analysis, the circuit is operated based on two operating modes. The modes are obtained by complementary switching of the converter's switches $S_{1}$ and $S_{2}$.

\subsection{Mode I}

During this operating mode, $\mathrm{S}_{1}$ is turned $\mathrm{ON}$ while $\mathrm{S}_{2}$ is turned OFF as shown in Figure $2 \mathrm{a}$.

The circuit equations during this mode are:

$$
\begin{gathered}
V_{L 1}=V_{C 2}-V_{C 1} \\
V_{L 2}=V_{g}
\end{gathered}
$$

\subsection{Mode II}

During this operating mode, $S_{1}$ is turned OFF while $S_{2}$ is turned $\mathrm{ON}$ as shown in Figure $2 b$. The circuit equations during this mode are:

$$
\begin{gathered}
V_{L 1}=V_{g}-V_{C 1} \\
V_{L 2}=V_{O 2}
\end{gathered}
$$

Applying volt-second balance on $\mathrm{L}_{1}$ yields

$$
D V_{C 2}-D V_{C 1}+V_{g}-V_{C 1}-D V_{g}+D V_{C 1}=0
$$


Applying volt-second balance on $\mathrm{L}_{2}$ yields

$$
D V_{g}+V_{C 2}(1-D)=0
$$

Simplifying (6) shows that

$$
V_{C 2}=-\frac{D}{1-D} V_{g}
$$

Substituting (7) into (5) and simplifying yields

$$
V_{C 1}=\frac{1-2 D}{1-D}
$$

From Figure $1, \mathrm{~V}_{\mathrm{O} 1}$ is in parallel with $\mathrm{C}_{1}$, thus

$$
V_{C 1}=V_{O 1}
$$

Also from Figure $1, \mathrm{~V}_{\mathrm{O} 2}$ is in parallel with $\mathrm{C}_{2}$, thus

$$
V_{C 2}=V_{O 2}
$$

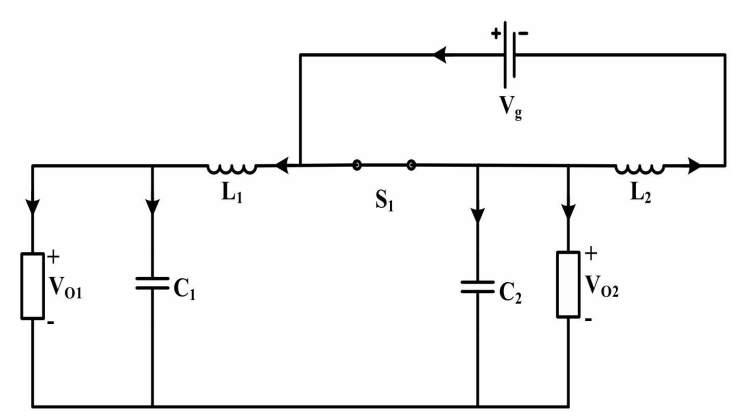

(a)

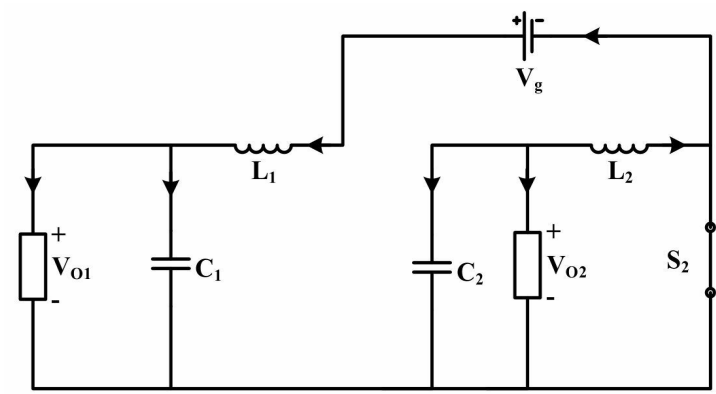

(b)

Figure 2. Equivalent circuit of the proposed converter during (a) mode I, (b) Mode II

\subsection{First output $\left(\mathrm{V}_{\mathrm{O1}}\right)$}

The expression for $\mathrm{V}_{\mathrm{O} 1}$ is obtained by substituting (9) into (8) as

$$
V_{O 1}=\frac{1-2 D}{1-D} \times V_{g}
$$

The gain of this output is

$$
A_{1}=\frac{V_{O 1}}{V_{g}}=\frac{1-2 D}{1-D}
$$

2.4. Second output $\left(\mathrm{V}_{\mathrm{O} 2}\right)$

The expression for $\mathrm{V}_{\mathrm{O} 2}$ is obtained by substituting (10) into (7) as

$$
V_{O 2}=\frac{-D}{1-D} \times V_{g}
$$

The gain of this output is

$$
A_{2}=\frac{V_{O 2}}{V_{g}}=\frac{-D}{1-D}
$$


A plot comparing the two different outputs of the converter $\mathrm{V}_{\mathrm{O} 1}$ and $\mathrm{V}_{\mathrm{O} 2}$ against duty ratio (D) is shown in Figure 3. The following can be deduced from Figure 3:

(a) Both the two outputs are capable of stepping up (boosting) or stepping down (bucking) the input voltage as $\mathrm{D}$ is varied from 0 to 1 . However, the buck operation in $\mathrm{V}_{\mathrm{O} 2}$ is inverted.

(b) As $\mathrm{D}$ is varied from 0 to 0.5 , the two outputs are less than or equal to the input voltage magnitude

(c) For $\mathrm{V}_{\mathrm{O} 2}$, varying the output from 0.5 to 1 results in boost operation

(d) For $\mathrm{V}_{\mathrm{O} 1}$, varying $\mathrm{D}$ from 0.5 to 0.667 results in inverted buck (stepping down) operation before achieving inverted boost operation from 0.667 to 1

(e) Two different buck operations could be achieved from $\mathrm{V}_{\mathrm{O} 1}$ namely: positive buck (from $\mathrm{D}=0$ to 0.5 ) and negative buck (from $\mathrm{D}=0.667$ to 1 )

(f) The positive and negative buck operation implies bidirectional buck capability [23, 17]. The bidirectional buck capability means that during the negative buck, energy is transferred from source to $\mathrm{V}_{\mathrm{O} 1}$ while during the positive buck, it could be transferred from $V_{O 1}$ to source [17] at lower voltage magnitude.

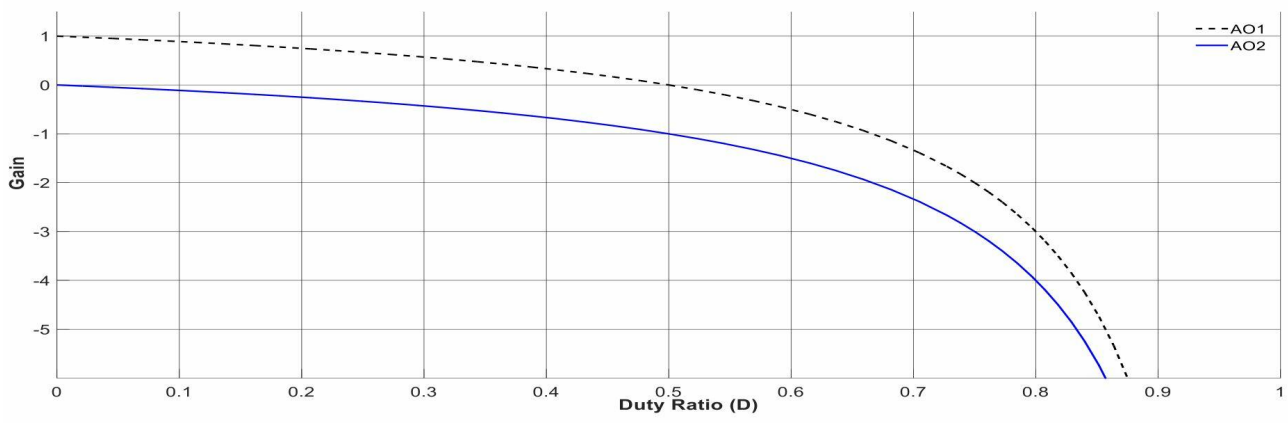

Figure 3. Comparison of voltage gains of the converter's two outputs against duty ratio (D)

\section{VERIFICATION}

Operation of the converter was verified by simulating a specifically designed prototype using MATLAB SIMULINK.

\subsection{Components selection}

The design equations of DC-DC q-ZSC derived in [24] and presented here as (15) through (18) were used to determine the components values for a prototype. The specifications for the prototype are given in Table 1.

$$
C_{1}=\frac{D(1-D) I_{O}}{V_{\Delta}(1-2 D) f V_{g}}
$$

Where $I_{O}$ is the output current, $f$ is the minimum operating frequency, $V_{\Delta}$ is the voltage ripple ratio, $V_{g}$ is the input voltage.

$$
\begin{gathered}
C_{2}=\frac{2(1-D) I_{O}}{V_{\Delta} f V_{g}} \\
L_{1}=\frac{D V_{g}}{f I_{\Delta} I_{O}}
\end{gathered}
$$

Where $\mathrm{I}_{\Delta}$ is the current ripple ratio.

$$
L_{2}=\frac{D(D-1) V_{g}}{f(D+1) I_{\Delta} I_{O}}
$$


Table 1. Design specifications

\begin{tabular}{lcc}
\hline Parameter & Minimum & Maximum \\
\hline Input Voltage $\left(\mathrm{V}_{g}\right)$ & $10 \mathrm{~V}$ & $15 \mathrm{~V}$ \\
Output Current $\left(\mathrm{I}_{O}\right)$ & $0.4 \mathrm{~A}$ & $2 \mathrm{~A}$ \\
Switching Frequency (f) & \multicolumn{2}{c}{$100 \mathrm{kHz}$} \\
Max Duty Ratio (D) & \multicolumn{2}{c}{0.7} \\
\hline
\end{tabular}

\subsection{Component values}

\subsubsection{Capacitor $1\left(\mathbf{C}_{1}\right)$}

$$
C_{1}=\frac{D_{\max }\left(1-D_{\max }\right) I_{O, \max }}{\left(1-2 D_{\max }\right) f_{\min } V_{\Delta} V_{g, \min }}
$$

$\mathrm{I}_{\mathrm{O}, \max }$ is the maximum output current, $\mathrm{f}_{\min }$ is the minimum frequency, $\mathrm{V}_{\Delta}$ is the voltage ripple ratio, $\mathrm{V}_{\mathrm{g}, \min }$ is the minimum input voltage.

$$
C_{1}=\frac{0.72 \times(1-0.72) \times 2}{1-(2 \times 0.72) \times 100 \times 10^{3} \times 0.2 \times 10} F=4.52 \mu F
$$

\subsubsection{Capacitor $2\left(\mathrm{C}_{2}\right)$}

$$
\begin{gathered}
C_{2}=\frac{2\left(1-D_{\max }\right) I_{O, \max }}{f_{\min } V_{\Delta} V_{g, \min }} \\
C_{2}=\frac{2 \times(1-0.72) \times 2}{100 \times 10^{3} \times 0.2 \times 10} F=5.6 \mu F \\
L_{1}=\frac{D_{\max } V_{g, \max }}{f_{\min } I_{\Delta} I_{O, \min }}
\end{gathered}
$$

Where $V_{g, \text { max }}$ is the maximum input voltage, $I_{\Delta}$ is the current ripple ratio and $I_{O \text {,min }}$ is the minimum output current.

$$
\begin{gathered}
L_{1}=\frac{0.72 \times 15}{100 \times 10^{3} \times 0.2 \times 0.4} H=1.35 \mathrm{mH} \\
L_{2}=\frac{D_{\max }\left(1-D_{\max }\right) V_{g, \max }}{\left(D_{\max }+1\right) f_{\min } I_{\Delta} I_{O, \min }} \\
L_{2}=\frac{0.72 \times(1-0.72) \times 15}{(0.72+1) \times 100 \times 10^{3} \times 0.2 \times 0.4} H=87.9 \mu \mathrm{H}
\end{gathered}
$$

The components values found in (20), (22), (24) and (26) implies the use of asymmetric components [25, 6, 3]

\subsection{Simulations and methods}

The components values obtained in (20), (22), (24) and (26) as shown in Table 2 were used to simulate the response of the proposed converter. This simulation was in order to verify the ideal operation of the converter. Thus, ideal components were used and parasitic resistances were neglected.

A load with resistance of $20 \Omega$ was connected to the first output (output 1) to consume a voltage $\mathrm{V}_{\mathrm{O} 1}$. Also, another load with resistance of $20 \Omega$ was connected to the second output (output 2) to consume a voltage $\mathrm{V}_{\mathrm{O} 2}$ as shown in Figure 1. To analyze the response of the converter at various input voltages $\left(\mathrm{V}_{\mathrm{g}}\right)$ and duty ratios (D), parametric sweep of $\mathrm{V}_{\mathrm{g}}$ and $\mathrm{D}$ for $10 \mathrm{~V} \leq \mathrm{V}_{\mathrm{g}} \leq 15 \mathrm{~V}$ with step size of $1 \mathrm{~V}$ and $0 \leq \mathrm{D} \leq 0.7$ with step size of 0.1 respectively. This implies that the converter's response was simulated for all possible operating voltages and duty ratios based on the design specifications and step size.

Some selected steady-state responses of the converter at minimum and maximum input voltages and duty ratios are shown in Figure 4a through Figure 5b. Since steady-state values of DC-DC converters contain 
ripples that are dependent of switching frequency and values of the reactive components due to charging and discharging, average values of the converter's steady-state output voltages and currents $\mathrm{V}_{\mathrm{O} 1}, \mathrm{~V}_{\mathrm{O} 2}, \mathrm{I}_{\mathrm{O} 1}$ and $\mathrm{I}_{\mathrm{O} 2}$ for every given $\mathrm{V}_{\mathrm{g}}$ and $\mathrm{D}$ were determined. Plots of these average output voltages and currents against $\mathrm{D}$ are shown in Figure $6 a$ and 6 b respectively.

The ripples in the output voltages and currents determined using Equation (27) where $\mathrm{A}$ is the voltage or current, $\mathrm{A}_{\Delta}(\%)$ is the ripple ratio in percentage, $\mathrm{A}_{\max }$ is the steady-state maximum value of the signal, $\mathrm{A}_{\min }$ is its minimum and $\mathrm{A}_{\mathrm{av}}$ is its average value.

$$
A_{\Delta}(\%)=\frac{A_{\max }-A_{\min }}{2 \times A_{a v}} \times 100
$$

The values of output voltages and currents along with their ripple values $\mathrm{V}_{\mathrm{O} 1 \Delta}(\%), \mathrm{V}_{\mathrm{O} 2 \Delta}(\%), \mathrm{I}_{\mathrm{O} 1 \Delta}(\%)$ and $\mathrm{I}_{\mathrm{O} 2 \Delta}(\%)$ for $10 \mathrm{~V} \leq \mathrm{V}_{\mathrm{g}} \leq 15 \mathrm{~V}$ and $0.3 \leq \mathrm{D} \leq 0.7$ are presented in Table 3 through Table $8.0 .3 \leq \mathrm{D} \leq 0.7$ was considered because the efficiency of complementary switched converters reduces when operated outside this range $[22,12,19]$. A significance of the the ripple ratio is to measure the appositeness of the adapted design equations. This is because very low ripple indicates overvalue while very high ripple indicates undervalue of reactive component.

Table 2. Summary of components values

\begin{tabular}{lcc}
\hline Component & Value & Unit \\
\hline $\mathrm{C}_{1}$ & 4.52 & $\mu \mathrm{F}$ \\
$\mathrm{C}_{2}$ & 5.6 & $\mu \mathrm{F}$ \\
$\mathrm{L}_{1}$ & 1350 & $\mu \mathrm{H}$ \\
$\mathrm{L}_{2}$ & 87.9 & $\mu \mathrm{H}$ \\
$\mathrm{R}_{O 1}$ & 20 & $\Omega$ \\
$\mathrm{R}_{O 2}$ & 20 & $\Omega$ \\
\hline
\end{tabular}

\section{RESULTS AND DISCUSSION}

Results of the proposed converter's response for some selected steady-state responses of the converter at minimum and maximum input voltages and duty ratios are shown in Figure $4 \mathrm{a}$ through Figure 5b. Figure 4a and Figure $4 \mathrm{~b}$ both show its response at $\mathrm{V}_{\mathrm{g}}=10$ but $\mathrm{D}=0.4$ and 0.6 respectively while Figure 5a and Figure 5 b both show its response at $\mathrm{V}_{\mathrm{g}}=15$ but $\mathrm{D}=0.4$ and 0.6 respectively. Table $3,4,5,6,7$ and Table 8 show the average output voltages and currents along with their percentage ripples.

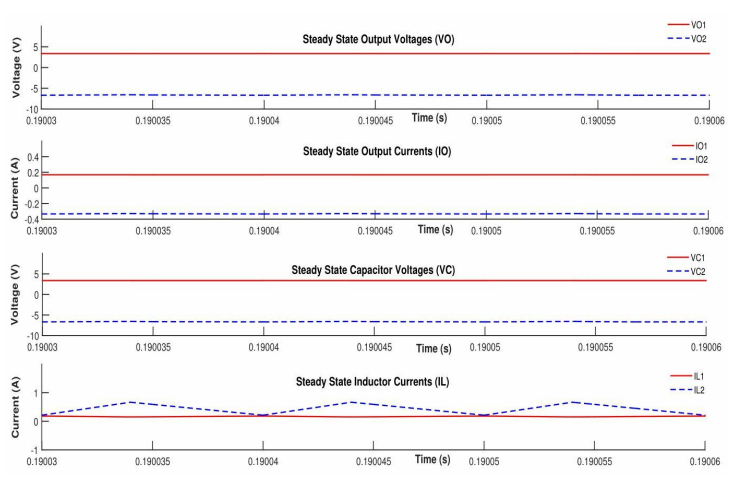

(a)

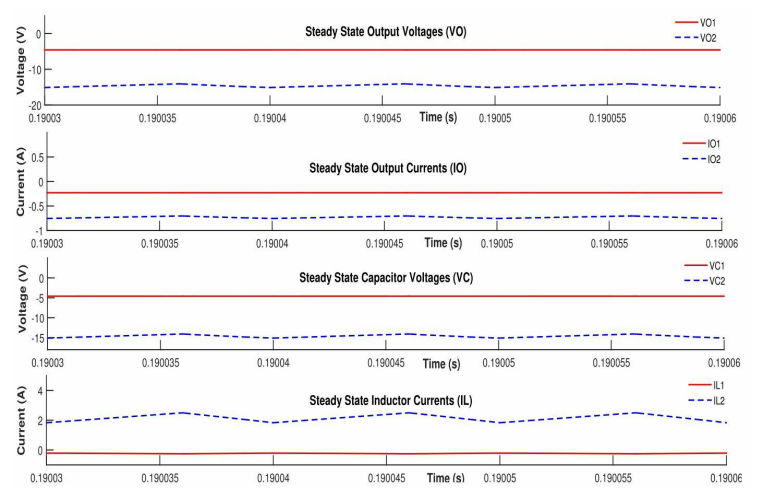

(b)

Figure 4. Steady state simulation response of the proposed converter showing output and capacitor voltages, output and inductor currents for (a) $\mathrm{V}_{g}=10 \mathrm{~V}$ and $\mathrm{D}=0.4$ (b) $\mathrm{V}_{g}=10 \mathrm{~V}$ and $\mathrm{D}=0.6$ 


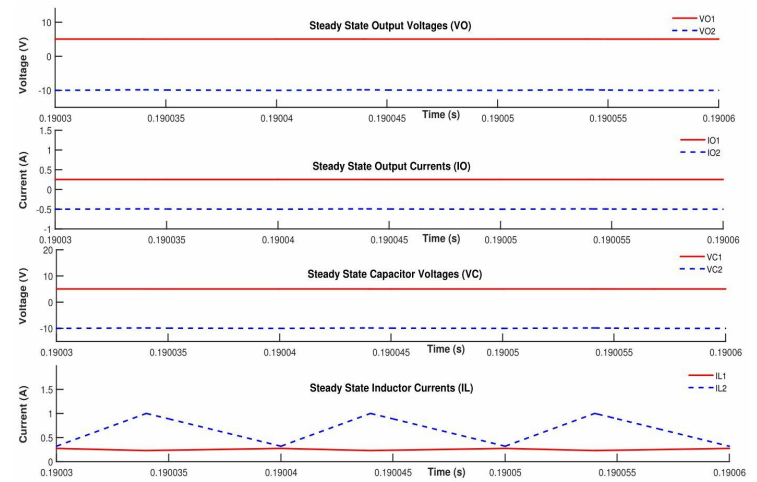

(a)

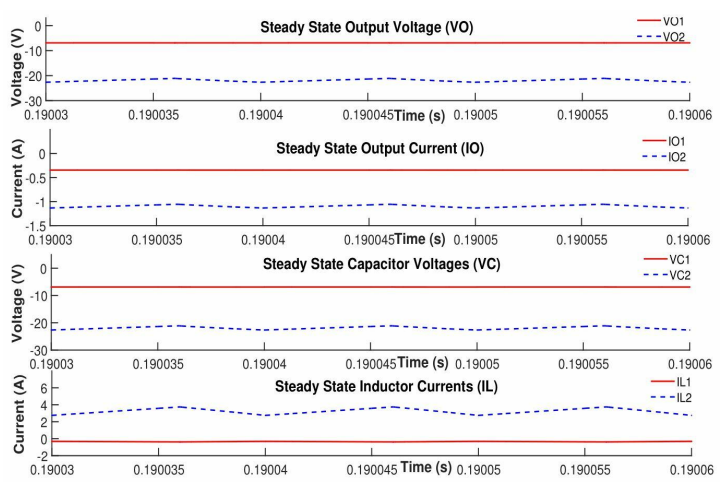

(b)

Figure 5. Steady state simulation response of the proposed converter showing output and capacitor voltages, output and inductor currents for (a) $\mathrm{V}_{g}=15 \mathrm{~V}$ and $\mathrm{D}=0.4$ (b) $\mathrm{V}_{g}=15 \mathrm{~V}$ and $\mathrm{D}=0.6$

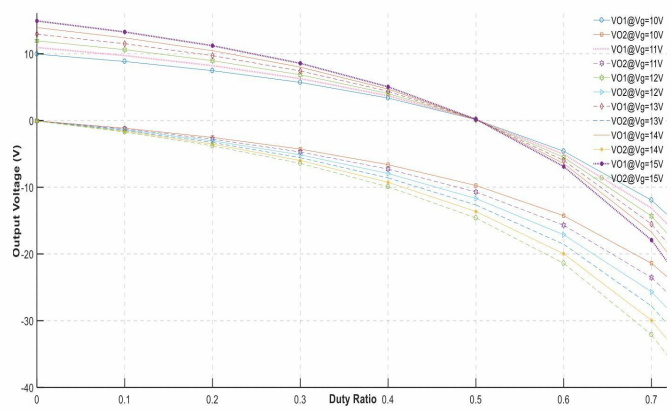

(a)

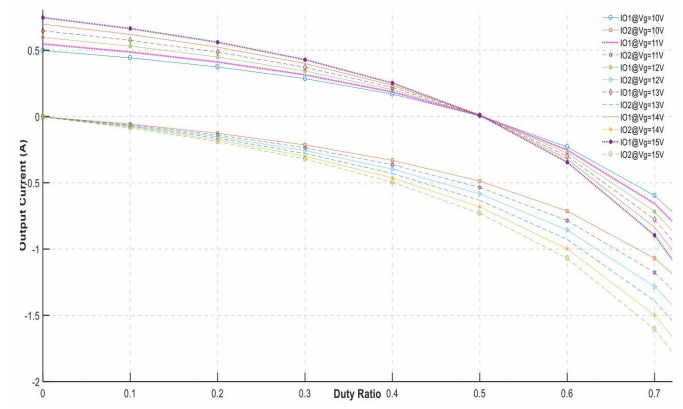

(b)

Figure 6. Plots of the proposed converter's steady state average (a) Output voltages against duty ratio for different input voltages (b) Output currents against duty ratio for different input voltages

Table 3. Average output voltages and currents of the proposed converter with their percentage ripples at $\mathrm{V}_{g}=10 \mathrm{~V}$ with $\mathrm{D}$ varied from 0.3 to 0.7

\begin{tabular}{ccccccccc}
\hline & & \multicolumn{7}{c}{$\mathrm{V}_{g}=10 \mathrm{~V}$} \\
$\mathrm{D}$ & $\mathrm{V}_{01}(\mathrm{~V})$ & $\mathrm{V}_{02}(\mathrm{~V})$ & $\mathrm{I}_{01}(\mathrm{~A})$ & $\mathrm{I}_{02}(\mathrm{~A})$ & $\mathrm{V}_{1 \Delta}(\%)$ & $\mathrm{V}_{2 \Delta}(\%)$ & $\mathrm{I}_{1 \Delta}(\%)$ & $\mathrm{I}_{2 \Delta}(\%)$ \\
\hline 0.3 & 5.714 & -4.2822 & 0.2857 & -0.2141 & 0.0465 & -0.8322 & 0.0465 & -0.8322 \\
0.4 & 3.3671 & -6.6146 & 0.1684 & -0.3307 & 0.0444 & -0.9026 & 0.0444 & -0.9026 \\
0.5 & 0.1266 & -9.7351 & 0.0063 & -0.4868 & 3.9975 & -2.2408 & 3.9975 & -2.2408 \\
0.6 & -4.5964 & -14.266 & -0.2298 & -0.7133 & -0.0994 & -3.6016 & -0.0994 & -3.6016 \\
0.7 & -11.942 & -21.393 & -0.5971 & -1.0697 & -0.0420 & -4.9488 & -0.0420 & -4.9488 \\
\hline
\end{tabular}

Table 4. Average output voltages and currents of the proposed converter with their percentage ripples at

\begin{tabular}{lcccccccc}
\multicolumn{8}{c}{$\mathrm{V}_{g}=11 \mathrm{~V}$ with D varied from 0.3 to 0.7} \\
\hline $\mathrm{D}$ & $\mathrm{V}_{01}(\mathrm{~V})$ & $\mathrm{V}_{02}(\mathrm{~V})$ & $\mathrm{I}_{01}(\mathrm{~A})$ & $\mathrm{I}_{02}(\mathrm{~A})$ & $\mathrm{V}_{1 \Delta}(\%)$ & $\mathrm{V}_{2 \Delta}(\%)$ & $\mathrm{I}_{1 \Delta}(\%)$ & $\mathrm{I}_{2 \Delta}(\%)$ \\
\hline 0.3 & 6.2853 & -4.7104 & 0.31426 & -0.2355 & 0.0465 & -0.8322 & 0.0465 & -0.8322 \\
0.4 & 3.7038 & -7.2761 & 0.1852 & -0.3638 & 0.0444 & -0.9026 & 0.0443 & -0.9026 \\
0.5 & 0.1392 & -10.71 & 0.0070 & -0.5355 & 3.9987 & -2.2405 & 3.9987 & -2.2405 \\
0.6 & -5.0561 & -15.693 & -0.2528 & -0.7846 & -0.0994 & -3.6016 & -0.0994 & -3.6016 \\
0.7 & -13.136 & -23.532 & -0.6568 & -1.1766 & -0.0420 & -4.9488 & -0.0420 & -4.9488 \\
\hline
\end{tabular}


Table 5. Average output voltages and currents of the proposed converter with their percentage ripples at

\begin{tabular}{lcccccccc}
\multicolumn{7}{c}{$\mathrm{V}_{g}=12 \mathrm{~V}$ with D varied from 0.3 to 0.7} \\
\hline $\mathrm{D}$ & $\mathrm{V}_{01}(\mathrm{~V})$ & $\mathrm{V}_{02}(\mathrm{~V})$ & $\mathrm{I}_{01}(\mathrm{~A})$ & $\mathrm{I}_{02}(\mathrm{~A})$ & $\mathrm{V}_{1 \Delta}(\%)$ & $\mathrm{V}_{2 \Delta}(\%)$ & $\mathrm{I}_{1 \Delta}(\%)$ & $\mathrm{I}_{2 \Delta}(\%)$ \\
\hline 0.3 & 6.8567 & -5.1389 & 0.3428 & -0.2569 & 0.0465 & -0.8322 & 0.0465 & -0.8322 \\
0.4 & 4.0405 & -7.9376 & 0.2020 & -0.3969 & 0.0444 & -0.9026 & 0.0443 & -0.9026 \\
0.5 & 0.1518 & -11.684 & 0.0076 & -0.5842 & 3.9987 & -2.2405 & 3.9987 & -2.2405 \\
0.6 & -5.5157 & -17.119 & -0.2758 & -0.8560 & -0.0994 & -3.6016 & -0.0994 & -3.6016 \\
0.7 & -14.33 & -25.672 & -0.7165 & -1.2836 & -0.0420 & -4.9488 & -0.0420 & -4.9488 \\
\hline
\end{tabular}

Table 6. Average output voltages and currents of the proposed converter with their percentage ripples at

\begin{tabular}{lcccccccc}
\multicolumn{7}{c}{$\mathrm{V}_{g}=13 \mathrm{~V}$ with D varied from 0.3 to 0.7} \\
\hline $\mathrm{D}$ & $\mathrm{V}_{01}(\mathrm{~V})$ & $\mathrm{V}_{02}(\mathrm{~V})$ & $\mathrm{I}_{01}(\mathrm{~A})$ & $\mathrm{I}_{02}(\mathrm{~A})$ & $\mathrm{V}_{1 \Delta}(\%)$ & $\mathrm{V}_{2 \Delta}(\%)$ & $\mathrm{I}_{1 \Delta}(\%)$ & $\mathrm{I}_{2 \Delta}(\%)$ \\
\hline 0.3 & 7.4282 & -5.5669 & 0.3714 & -0.2783 & 0.0464 & -0.8323 & 0.0464 & -0.8323 \\
0.4 & 4.3772 & -8.599 & 0.2187 & -0.4300 & 0.0444 & -0.9026 & 0.0444 & -0.9026 \\
0.5 & 0.1645 & -12.658 & 0.0082 & -0.6329 & 3.9987 & -2.2405 & 3.9987 & -2.2405 \\
0.6 & -5.9754 & -18.546 & -0.2998 & -0.9273 & -0.0994 & -3.6016 & -0.0994 & -3.6016 \\
0.7 & -15.525 & -27.811 & -0.7762 & -1.3906 & -0.0420 & -4.9488 & -0.0420 & -4.9488 \\
\hline
\end{tabular}

Table 7. Average output voltages and currents of the proposed converter with their percentage ripples at $\mathrm{V}_{g}=14 \mathrm{~V}$ with $\mathrm{D}$ varied from 0.3 to 0.7

\begin{tabular}{lcccccccc}
\hline \multicolumn{7}{c}{$\mathrm{D}$} & \multicolumn{7}{c}{$\mathrm{V}_{g}=14 \mathrm{~V}$} \\
\hline 0.3 & 7.9997 & -5.9951 & 0.4000 & -0.2998 & 0.0464 & -0.8322 & 0.0464 & -0.83217 \\
0.4 & 4.7139 & -9.2605 & 0.2357 & -0.4630 & 0.0443 & -0.9026 & 0.0443 & -0.9026 \\
0.5 & 0.1772 & -13.629 & 0.0089 & -0.6815 & 3.9975 & -2.2408 & 3.9975 & -2.2408 \\
0.6 & -6.435 & -19.973 & -0.3218 & -0.9986 & -0.0994 & -3.6016 & -0.0994 & -3.6016 \\
0.7 & -16.719 & -29.95 & -0.8360 & -1.4975 & -0.0420 & -4.9488 & -0.0420 & -4.9488 \\
\hline
\end{tabular}

Table 8. Average output voltages and currents and their percentage ripples of the proposed converter at $\mathrm{V}_{g}=15 \mathrm{~V}$ with D varied from 0.3 to 0.7

\begin{tabular}{lcccccccc}
\hline \multicolumn{7}{c}{$\mathrm{V}_{g}=15 \mathrm{~V}$} \\
$\mathrm{D}$ & $\mathrm{V}_{01}(\mathrm{~V})$ & $\mathrm{V}_{02}(\mathrm{~V})$ & $\mathrm{I}_{01}(\mathrm{~A})$ & $\mathrm{I}_{02}(\mathrm{~A})$ & $\mathrm{V}_{1 \Delta}(\%)$ & $\mathrm{V}_{2 \Delta}(\%)$ & $\mathrm{I}_{1 \Delta}(\%)$ & $\mathrm{I}_{2 \Delta}(\%)$ \\
\hline 0.3 & 8.5711 & -6.4233 & 0.4286 & -0.3212 & 0.0465 & -0.8323 & 0.0465 & -0.8323 \\
0.4 & 5.0506 & -9.922 & 0.2525 & -0.4961 & 0.0444 & -0.9026 & 0.0444 & -0.9026 \\
0.5 & 0.19 & -14.603 & 0.0095 & -0.7301 & 3.9975 & -2.2408 & 3.9975 & -2.2408 \\
0.6 & -6.8947 & -21.399 & -0.3447 & -1.07 & -0.0994 & -3.6016 & -0.0994 & -3.6016 \\
0.7 & -17.913 & -32.09 & -0.8957 & -1.6045 & -0.0420 & -4.9488 & -0.0420 & -4.9488 \\
\hline
\end{tabular}

Plots of these average output voltages and currents against D are shown in Figure $6 \mathrm{a}$ and $6 \mathrm{~b}$ respectively. Results of Figure 4a through Figure 5b confirmed the operation of the proposed converter. As presented in [17], the output voltage and current of port $1\left(\mathrm{~V}_{\mathrm{O} 1}\right.$ and $\mathrm{I}_{\mathrm{O} 1}$ are bipolar; positive for $\mathrm{D}<0.5$ and inverted for $\mathrm{D}>0.5)$. This is captured in (9), with the $\mathrm{V}_{\mathrm{O} 1}$ expected to be null at $\mathrm{D}=0.5$. However as shown in Table 3 through Table $8, \mathrm{~V}_{\mathrm{O} 1}$ at $\mathrm{D}=0.5$ is slightly greater than 0 (zero) with its magnitude proportional to the $\mathrm{V}_{\mathrm{g}}$ as shown in Figure 7 . All these values are $1.27 \%$ of the corresponding $\mathrm{V}_{\mathrm{g}}$.

The ripples for output port $1\left(\mathrm{~V}_{1 \Delta}(\%)\right.$ and $\left.\mathrm{I}_{1 \Delta}(\%)\right)$ presented in Table 3 through Table 8 are minimal except at $\mathrm{D}=0.5$, where it is maximum at $4 \%$ due to the ideal 0 (zero) output. The ripples for output port 2 are significantly higher than the corresponding ones for output 1 . Reasons for the wide variation in the ripple ratio are:

(a) The design equations used to determine the components values are not specifically derived for the proposed converter but for a related topology with a single output in which the output was taken from port 2.

(b) The components used for $\mathrm{C}_{1}$ and $\mathrm{L}_{1}$ are oversized because the design equations were not specifically derived for this converter. 
The plots of average output voltages and currents of the proposed converter's simulation responses against duty ratio for different input voltages shown in Figure $6 \mathrm{a}$ and Figure $6 \mathrm{~b}$ respectively show that the shape of the plot is identical with the theoretical gain curve of the converter shown in Figure 3 . The average output voltages of output port 1 are about $89.56 \%$ to $101 \%$ of the theoretical value for $0.3 \leq \mathrm{D} \leq 0.7$ except at $\mathrm{V}_{\mathrm{g}}=15 \mathrm{~V}$ where it is $96 \%$ to $108.2 \%$. For port $2, \mathrm{~V}_{\mathrm{O} 2}$ is $91.7 \%$ to $99.9 \%$ of the theoretical value with the ratio proportional to $\mathrm{D}$. It is important to note that in some cases the simulation output for some parameters are above or very close to the theoretical ideal values as seen above. This is due to the effect of dead-time/OC that exists in the switching signal [6].

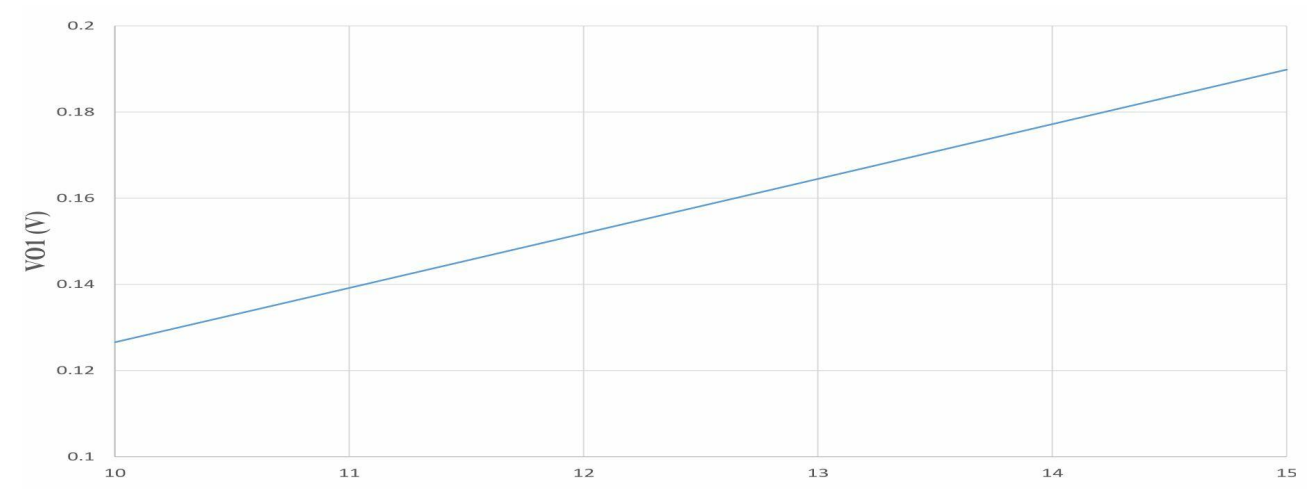

Figure 7. Plot of $\mathrm{V}_{\mathrm{O} 1}$ at $\mathrm{D}=0.5$ against $\mathrm{V}_{\mathrm{g}}$

\section{CONCLUSION}

A q-ZSC with two outputs has been proposed. The gain of each output has been derived. The operations of the converter was simulated at different input voltages and duty ratios using MATLAB SIMULINK. The average steady-state output current and voltages of each simulation was determined, analyzed and their ripple ratios determined. Comparison of the average output voltages of the two outputs show agreement with the theoretical outputs given by their ideal gain equations. The ripples present in all the outputs of the proposed converter were lower than $5 \%$.

\section{REFERENCES}

[1] J.-H. Park, H.-G. Kim, E.-C. Nho, T.-W. Chun, and J. Choi, "Grid-connected PV system using a quasi-zsource inverter," in 2009 Twenty-Fourth Annual IEEE Applied Power Electronics Conference and Exposition, 2009.

[2] K. Tsang and W. Chan, "A single switch DC/DC converter with galvanic isolation and input current regulation for photovoltaic systems," Solar Energy, vol. 119, pp. 203-211, sep 2015.

[3] M. Ado, A. Jusoh, and T. Sutikno, "Asymmetric quasi impedance source buck-boost converter," International Journal of Electrical and Computer Engineering, vol. 10, no. 2, pp. 2128-2138, 2020. [Online]. Available: http://ijece.iaescore.com/index.php/IJECE/article/view/21472/pdf

[4] B. G. Gang, H. Kim, and S. Kwon, "Ground simulation of a hybrid power strategy using fuel cells and solar cells for high-endurance unmanned aerial vehicles," Energy, vol. 141, pp. 1547-1554, dec 2017.

[5] D. Guilbert, A. Gaillard, A. NDiaye, and A. Djerdir, "Energy efficiency and fault tolerance comparison of DC/DC converters topologies for fuel cell electric vehicles," in 2013 IEEE Transportation Electrification Conference and Expo (ITEC). Detroit: IEEE, 2013. [Online]. Available: https://ieeexplore.ieee.org/stamp/stamp.jsp?tp=\&arnumber=6574513

[6] M. Ado, A. Jusoh, M. H. Muda, F. binti Atan, and A. U. Mutawakkil, "A Prototype of DC-DC Quasi - Z-Source Buck-Boost Converter," in 10th IEEE Control and System Graduate Research Colloquium, 2019, pp. 184-188. [Online]. Available: https://ieeexplore.ieee.org/document/8837062

[7] H. Fathabadi, "Novel high efficiency dc/dc boost converter for using in photovoltaic systems," Solar Energy, vol. 125, pp. 22 - 31, 2016. [Online]. Available: http://www.sciencedirect.com/science/article/pii/S0038092X15006702 
[8] M. S. Bin Arif, S. M. Ayob, S. M. Yahya, U. Mustafa, M. Ado, and Z. A. Khan, "Effect of Zn- $\mathrm{H}_{2} \mathrm{O}$ nanofluid back-flow channels on the efficiency and electrical power output of a solar PV panel used in standalone PV system," in 10th IEEE PES Asia-Pacific Power and Energy Engineering Conference, 2018, pp. 493-497. [Online]. Available: https://ieeexplore.ieee.org/stamp/stamp.jsp?tp=\&arnumber=8566544

[9] M. Kalantar and M. G., "Posicast control within feedback structure for a DC-DC single ended primary inductor converter in renewable energy applications," Applied Energy, vol. 87, no. 10, pp. 3110-3114, oct 2010.

[10] F. Z. Peng, “Z-Source Inverter,” 37th IEEE Industry Applications Conference, vol. 2, pp. 775-781, 2002.

[11] M. Ado, A. Jusoh, M. J. A. Aziz, M. Kermadi, and A. U. Mutawakkil, "DC-DC q-ZSC with Buck-Boost Converter Gain," in 9th IEEE Control and System Graduate Research Colloquium, 2018, pp. 85-88.

[12] A. Chub, D. Vinnikov, F. Blaabjerg, and F. Z. Peng, "A review of galvanically isolated impedance-source DC-DC converters,” IEEE Transactions on Power Electronics, vol. 31, no. 4, pp. 2808-2828, 2016.

[13] M. Hanif, M. Basu, and K. Gaughan, "Understanding the operation of a Z-source inverter for photovoltaic application with a design example," IET Power Electronics, vol. 4, no. 3, pp. 278-287, 2011.

[14] P. C. Loh, F. Gao, and F. Blaabjerg, "Embedded EZ-Source Inverters," IEEE Transactions on Industry Applications, vol. 46, no. 1, pp. 256-267, 2010.

[15] Y. Li, S. Jiang, J. G. Cintron-Rivera, and F. Z. Peng, "Modeling and control of quasi-z-source inverter for distributed generation applications," IEEE Transactions on Industrial Electronics, vol. 60, no. 4, pp. 1532-1541, 2013.

[16] J. Anderson and F. Z. Peng, "Four quasi-Z-Source inverters," in 2008 IEEE Power Electronics Specialists Conference, 2008, pp. 2743-2749.

[17] D. Cao and F. Z. Peng, “A Family of Z-source and Quasi-Z-source DC-DC Converters,” 2009 TwentyFourth Annual IEEE Applied Power Electronics Conference and Exposition, pp. 1097-1101, 2009.

[18] D. Vinnikov and I. Roasto, "Quasi-z-source-based isolated dc/dc converters for distributed power generation," IEEE Transactions on Industrial Electronics, vol. 58, no. 1, pp. 192-201, 2011.

[19] V. P. Galigekere and M. K. Kazimierczuk, "Analysis of PWM Z-source DC-DC converter in CCM for steady state," IEEE Transactions on Circuits and Systems I: Regular Papers, vol. 59, no. 4, pp. 854-863, 2012.

[20] I. Roasto, D. Vinnikov, J. Zakis, and O. Husev, "New shoot-through control methods for qzsi-based dc/dc converters," IEEE Transactions on Industrial Informatics, vol. 9, no. 2, pp. 640-647, 2013.

[21] M. Ado, A. Jusoh, S. M. Ayob, M. H. Ali, and G. S. M. Galadanchi, "Buck-Boost Converter with q-ZSC Topology," in 5th IET International Conference on Clean Energy and Techonology. IET, 2018.

[22] M. Ado, A. Jusoh, A. U. Mutawakkil, and S. M. Ayob, "Two q-ZSCs with Efficient Buck-Boost Gain," in 10th IEEE PES Asia-Pacific Power and Energy Engineering Conference, 2018, pp. 252-256.

[23] M. Ado, A. Jusoh, T. Sutikno, and M. Ado, "Extended family of DC-DC quasi-Z-source converters," International Journal of Electrical and Computer Engineering (IJECE), vol. 9, no. 6, pp. 4540-4555, 2019.

[24] M. Ado, A. Jusoh, and N. M. Nordin, "Design Equations for DC-DC Quasi-ZSC," in 4th IEEE Conference on Energy Conversion (CENCON 2019), Yogyakarta, 2019.

[25] M. Ado, A. Jusoh, A. U. Mutawakkil, and T. Sutikno, "Dynamic model of a DC-DC quasi-Z-source converter ( q-ZSC )," International Journal of Electrical and Computer Engineering (IJECE), vol. 9, no. 3, pp. 1585-1597, 2019.

\section{BIOGRAPHIES OF AUTHORS}

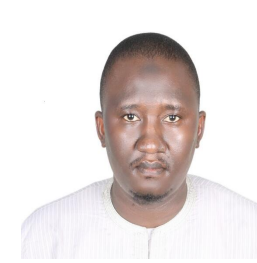

Muhammad Ado is a researcher at Universiti Teknologi Malaysia (UTM) where he completed his Ph.D. He has been a lecturer with Bayero University, Kano, Nigeria, where he obtained his Bachelor and Master degrees in Electronics in 2009 and 2016 respectively. His research interests include power converters, modelling and control, artificial intelligence and semiconductor physics. He is affiliated with IEEE as student member and Nigerian Institute of Physics (NIP) as a member. In IEEE Access, IET Power Electronics, International journal of electronics and other scientific publications, he serves as invited reviewer. 


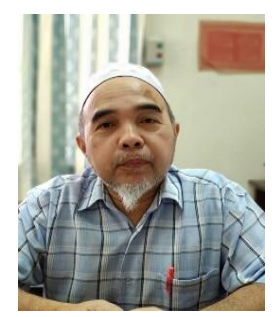

Awang Jusoh was born in Terengganu, Malaysia in 1964. He received his B. Eng. (Hons) from Brighton Polytechnic, UK, in 1988. He obtained his MSc. and PhD. from The University of Birmingham, UK in 1995 and 2004, respectively. Since 1989, he has been a lecturer at Universiti Teknologi Malaysia and is now an Associate Professor at the Department of Power Engineering, School of Electrical Engineering, Faculty of Engineering, Universiti Teknologi Malaysia, Malaysia. His research interests include all areas of power electronics systems and renewable energy.

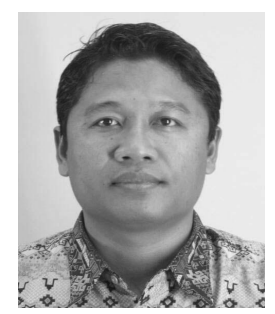

Tole Sutikno is an Associate Professor in Electrical \& Computer Engineering Department Universitas Ahmad Dahlan, Yogyakarta, Indonesia. He received B.Eng., M.Eng, and Ph.D.degrees in 1999, 2004 and 2016 respectively. He has over 200 publications to his credit. His research interests include power electronics, motor drives, industrial electronics, Industrial application, FPGA application, intelligence control and industrial informatics.

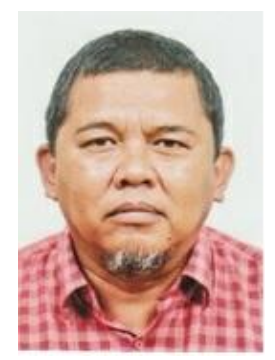

Mohd Hanipah Muda is currently working as a lecturer at University College TATI (UC TATI) at Faculty of Electrical Engineering Technology. He graduated from Universiti Teknologi Malaysia (UTM) in 1989. He has been a lecturer at Universiti Teknologi Malaysia and also as Senior Executive at Tenaga Nasional Berhad Research Sdn Bhd (TNBR) until 1997. His research interests include power electronics, power monitoring and Internet of Things (IOT).

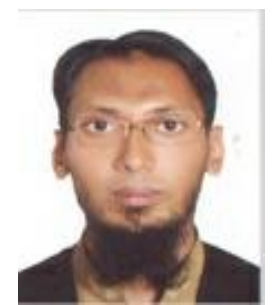

Zeeshan Ahmad Arfeen is an Assistant Professor at "The Islamia University of Bahawalpur", Pakistan in Electrical Power Engineering Department since 2011. He is a doctoral student from Universiti Teknologi Malaysia (UTM). His current research interests include Electric Vehicles, microgrid, energy management system and sustainable energy. He is a reviewer of many indexed Journals. 